\title{
Gravity and Magnetic Investigations in the Guiana Basin, Western Equatorial Atlantic
}

\section{ABSTRACT}

A free-air gravity map of the Guiana Basin between $15^{\circ} \mathrm{N}$. and $6^{\circ} \mathrm{S}$. in the western equatorial Atlantic, using all available shipboard and pendulum data, is presented. The gravity field is interpreted in terms of short wave-length components directly related to topographic features and a long wave-length regional field which is independent of surface or basement relief. The regional field is negative throughout the survey area, varying from -15 to $-40 \mathrm{mgal}$.

The magnetic anomalies over the large equatorial fracture zones indicate that the fracture zone trough is an area of zero or greatly reduced magnetization within a zone in which the magnetization is induced rather than remanent. Only about half of the gravity anomaly over the fracture zone can be assigned to topographic relief implying the presence of excess mass under the fracture zones. The gravity and magnetic evidence together suggest that large fracture zones serve as the site of intrusion of ultrabasic rocks from depth.

The deformation of the lithosphere due to the sediment load of the Amazon cone and the resulting gravity anomalies were computed for various flexural rigidities, using two-dimensional elastic beam theory. The value giving the best fit to the observed gravity anomalies in both wave length and amplitude is $2 \times 10^{23}$ Newton meters $(\mathrm{nt} \mathrm{m})\left(2 \times 10^{30}\right.$ dyne $\left.\mathrm{cm}\right)$. This implies an effective lithospheric thickness of $30 \mathrm{~km}$. It is suggested that the lithosphere behaves somewhat as a Kelvin (viscoelastic solid) material in its response to imposed longterm loads, approaching a minimum apparent flexural rigidity of $2 \times 10^{30}$ dyne $\mathrm{cm}$ asymptotically in a period of a few million years.

\section{INTRODUCTION}

Prior to 1967 , very little geophysical data had been gathered in a systematic manner from the equatorial Atlantic. Most of that which was available came from ships passing through, bound to or from the South Atlantic. However, since that time, reconnaissance and site surveys have been made in the region, including several by R/V Vema and R/V Conrad, and more than $20,000 \mathrm{mi}$ of continuous shipboard gravity and magnetic data are now available.

This study is concerned with the area from the Mid-Atlantic Ridge to the South American coast between the latitudes of $15^{\circ} \mathrm{N}$. and $6^{\circ} \mathrm{S}$., the limits roughly defining the Guiana Basin, which includes the Demerara and Ceara Abyssal Plains. An index map of the area of the survey is given in Figure 1.

A prominent feature of the area is the presence of numerous, closely spaced fracture zones including the Vema, St. Paul's, Romanche, and Chain fracture zones (Heezen and others, 1964a, 1964b, 1969). They offset the Mid-Atlantic Ridge by nearly 2,000 mi and, along with the corresponding offsets in the continental margins, undoubtedly played an important role in controlling the early development of the South Atlantic (Le Pichon and Hayes, 1971). Another important influence on the geology of the basin is the Amazon River, which annually discharges more than 300 million tons of sediment (Holoman, 1968) building a cone more than $500 \mathrm{~km}$ out onto the abyssal plain and spreading a thick ubiquitous blanket of sediment over the basin. The Amazon cone and the Ceara Rise, a 1-km-high topographic feature, serve to divide the basin nearly in half. The southern half is occupied by the Ceara Abyssal Plain which has an 
average depth of nearly $2,400 \mathrm{fm}$. The northern portion contains the Demerara Abyssal Plain at a depth of more than $2,500 \mathrm{fm}$.

The continental margin of the north coast of Brazil consists of an extremely steep continental slope with a gentle, poorly developed rise. The North Brazilian Ridge, first described by Hayes and Ewing (1969), parallels the coast in about $2,000 \mathrm{fm}$ of water at a distance of 150 to $200 \mathrm{~km}$ seaward of the base of the continental slope. Numerous seamounts are present to the east of $40^{\circ} \mathrm{W}$. between the North Brazilian Ridge and the continental margin.

The geology of the coastal area of Brazil is dominated by a series of Mesozoic sedimentary basins. These basins, some of which contain more than $3,000 \mathrm{~m}$ of Cretaceous sediments, have their southern boundary on the continent and extend an unknown distance onto the continental shelf (Mesner and Wooldridge, 1964). Francheteau and Le Pichon (1972) have suggested that the northern boundary of the coastal basins are formed by the continental extensions of the equatorial fracture zones.

The main purpose of the first portion of this study is to describe and interpret the gravity field in this area, and also to describe and attempt to explain the magnetic anomaly over the fracture zones. The second part will attempt to use the gravity anomalies associated with the Amazon cone to determine the flexure of the lithosphere due to the load of sediments, and to determine some gross properties of the lithosphere in this region.

\section{GRAVITY DATA}

The gravity data used to prepare this report were gathered on eleven different cruises over a period of eight years. The instrumentation and details of data collection are summarized in Table 1 . It can be seen that satellite navigation and corrections for cross coupling were employed on all except the earliest cruises. In particular, both of these were available during extended surveys conducted during Vema Cruises 25 and 26 and Conrad Cruises 13 and 15.

Fifty-six track crossings were examined to determine the consistency of the data. A mean difference of $8.1 \mathrm{mgal}$ with a standard deviation of $8.7 \mathrm{mgal}$ was determined. However, eight crossings were considered suspect, as they occurred in areas of large gradients or because of discrepancies in the recorded depth at the crossing, implying navigational errors. When these crossirgs are eliminated, the mean difference becomes 5.5 mgai with a standard deviation of $5.4 \mathrm{mgal}$. Crossings where both legs were equipped for satellite navigation showed a mean difference of $4.1 \mathrm{mgal}$ with a standard deviation of $3.15 \mathrm{mgal}-$-indicating that, to an extent, the error in the earlier legs can be attributed to navigational uncer:ainties. These are also, in general, the legs on which cross-couplirg corrections were not made. As a result, values from satellite-navigationequipped cruises were favored in contouring, although the adjustment was never very large.

It was found necessary, however, to correct one cruise, Vema 26 Leg 7, 'jy a constant factor of $25 \mathrm{mgal}$ to obtain internal consistency. This is admittedly a rather severe correction, especially since the problem was confined to only one leg of Vema Cruise 26, and no immediate cause for a systematic error of this magnitude, such as a tare or an error in making a port tie-in with a land gravity station, could be determined.

The data were also compared at crossings with data from $H$. Neth. M. S. Luymes provided by B. J. Collelte of the Vening Meinesz Laboratory. No corrections for cross coupling were made for the Luymes data which were collected on an east-west traverse along $7^{\circ} \mathrm{N}$. Eight crossings with Vema and Conrad cruises other than Vema 26 showed an average absolute difference of $5.2 \mathrm{mg}$ al with the Luymes data an average of $1.5 \mathrm{mg}$ al higher than the Vema and Conrad data.

\section{FREE-AIR GRAVITY ANOMALY MAP}

A free-ai: gravity anomaly map of the Guiana Basin is presented in Figure 1. The control for the map is shown by the dotted lines, each dot of which is at the location of a gravity measurement used in constructing the map. Spot values are given at the locations indicated by larger dots. Additional pendulum measurements (Vening Meinesz, 1948; Worzel, 1965) were also employed and are shown by the largest dots. The control is considered adequate for delineating anomalies to the west of the Mid-Atlantic Ridge except for an area in the Demerara Abyssal Flain directly to the southwest of the Vema Fracture Zone. The available evidence does not warrant extrapolation of the trends estabiished farther to the east into this area. The fact that short wavelength gravity undulatiors and topography 





TABLE 1. INSTRUMENTATION USED FOR DATA COLLECTION

\begin{tabular}{|c|c|c|c|c|c|}
\hline Ship and cruise & Gravimeter & Platform & $\begin{array}{l}\text { Cross-coupling } \\
\text { correction }\end{array}$ & Navigation & Comments \\
\hline Conrad 8, leg 1 & Gss $2-6$ & $\begin{array}{l}\text { Lamont platform } \\
\text { with Mk IV Mod. zero } \\
\text { as vertical reference }\end{array}$ & No & Celestial & \\
\hline Conrad 9, leg 3 & Gss 2-6 & $\begin{array}{l}\text { Anschutz with ofl- } \\
\text { erected gyro }\end{array}$ & No & Satellite & $\begin{array}{l}\text { Cross-coupling } \\
\text { monitored but no } \\
\text { corrections made }\end{array}$ \\
\hline Conrad 13, leg 11 & Gss 2-31 & $\begin{array}{l}\text { Anschutz with } \\
\text { electrically erected } \\
\text { gyro }\end{array}$ & Yes & Satellite & $\begin{array}{l}\text { Possible bad base } \\
\text { value for tie-in } \\
\text { in Abidjan }\end{array}$ \\
\hline Conrad 15, leg 9 & Gss 2-31 & $\begin{array}{l}\text { Anschutz with } \\
\text { electrically erected } \\
\text { gyro }\end{array}$ & Yes & Satellite & \\
\hline Vema $18, \operatorname{leg} 3$ & Gss $2-12$ & $\begin{array}{l}\text { Alidade with Mk IV } \\
\text { Mod. zero as vertical } \\
\text { reference }\end{array}$ & No & Celestial & \\
\hline Vema 20, leg 2 & Gss $2-12$ & $\begin{array}{l}\text { Anschutz with } \\
\text { oil-erected gyro }\end{array}$ & No & Celestial & \\
\hline Vema 20, leg 12 & Gss 2-12 & $\begin{array}{l}\text { Alidade with Mk IV } \\
\text { Mod. zero as vertical } \\
\text { reference }\end{array}$ & No & Celestial & \\
\hline Vema $22, \operatorname{leg} 2$ & Gss $2-12$ & $\begin{array}{l}\text { ATidade with Mk IV } \\
\text { Mod. zero as vertical } \\
\text { reference }\end{array}$ & Yes & Celestial & \\
\hline Vema 24, leg 13 & Gss $2-12$ & $\begin{array}{l}\text { Lamont platform with } \\
\text { Mk IV Mod. zero } \\
\text { vertical reference }\end{array}$ & Yes & Satellite & \\
\hline Vema 25 , leg T & Gss $2-12$ & $\begin{array}{l}\text { Lamont platform } \\
\text { with Mk IV Mod. zero } \\
\text { as vertical reference }\end{array}$ & Yes & Satellite & \\
\hline Vema $25, \operatorname{leg} 2$ & Gss $2-12$ & $\begin{array}{l}\text { Lamant platform } \\
\text { with Mk IV Mod. Zero } \\
\text { as vertical reference }\end{array}$ & Yes & Satellite & \\
\hline Vema $25, \operatorname{leg} 3$ & Gss 2-12 & $\begin{array}{l}\text { Lamont platform } \\
\text { with Mk IV Mod. zero } \\
\text { as vertical reference }\end{array}$ & Yes & Satellite & \\
\hline Vema 26 , leg 7 & Gss $2-12$ & $\begin{array}{l}\text { Anschutz with oil- } \\
\text { erected gyro }\end{array}$ & Yes & Satellite & $\begin{array}{l}\text { All gravity values } \\
\text { lowered by } 25 \text { mgal }\end{array}$ \\
\hline Vema 27, leg 9 & Gss $2-9$ & $\begin{array}{l}\text { Anschutz with } \\
\text { electrically erected } \\
\text { gyro }\end{array}$ & Yes & Satellite & $\begin{array}{l}\text { No tie-in made at } \\
\text { beginning of leg }\end{array}$ \\
\hline
\end{tabular}

are very highly correlated (Talwani and others, 1972) was used to assist in contouring between tracks.

The most striking pattern on the free-air anomaly map is a strong east-west lineation due to the large closely spaced fracture zones. The anomalies are typically of a magnitude of between 25 and $75 \mathrm{mgal}$ and a width of less than $100 \mathrm{~km}$. Away from the Mid-Atlantic Ridge, the fracture zones are, in general, characterized by both a topographic and a gravity high. Near the Mid-Atlantic Ridge crest, where sediments are thin or missing, one sees both positive and negative anomalies. Away from the ridge, the troughs are filled with sediments, causing the gravity lows to be diminished. This may be seen on Figure 2 by noting the change in the signature of the Romanche fracture zone between profile V2206 which crosses the active transform section and V2202 much farther to the west, or of the small fracture zones near $4^{\circ} \mathrm{N}$. from profile V2709 near the ridge crest to V2502 in the Guiana Basin. However, on the African side of the MidAtlantic Ridge, the Romanche fracture zone is characterized by a 50 -mgal relative low all the way to the continental margin. The minimum remains even after the trough becomes filled with sediments. This is true to an extent in the western basin also, as the gravity field is depressed for $100 \mathrm{~km}$ to the south of the fracture zone in profiles V2709 and V2202. This is, however, much broader and less pronounced than the anomalies on the African side.

The Amazon cone is characterized by a band of high free-air gravity on the shelf and upper 


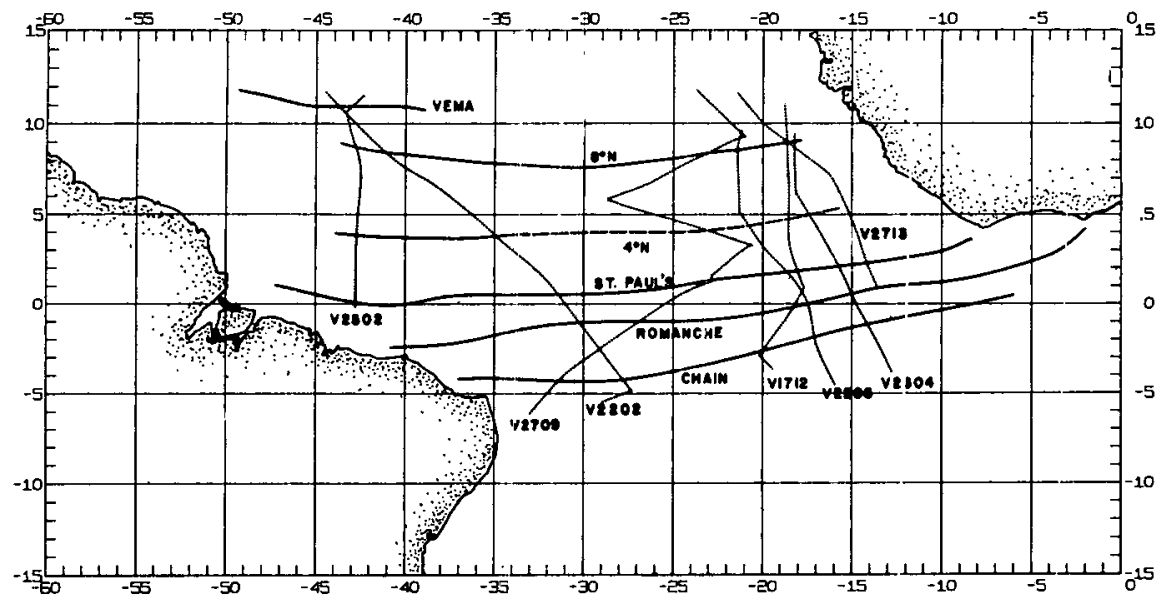

TOPOGRAPHY
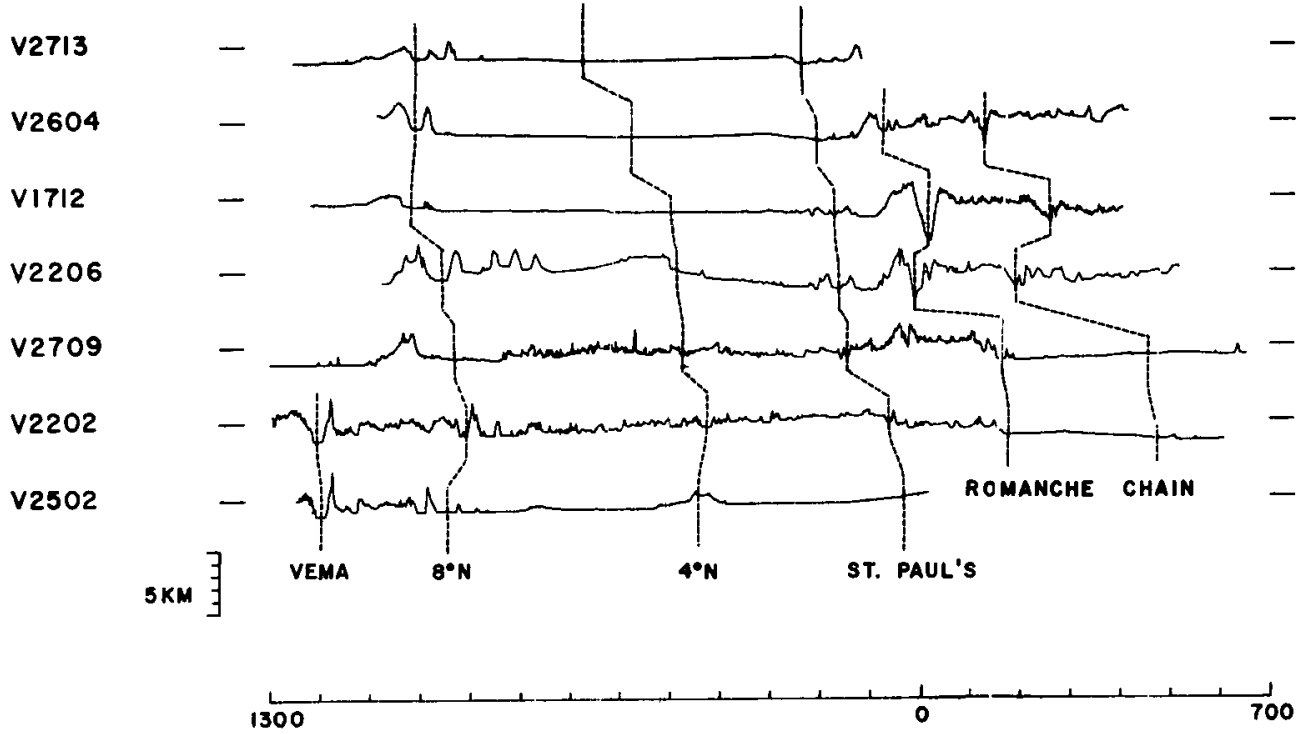

Figure 2. Projected topography, free-air gravity, and magnetic anomaly profiles over the equatorial fracture zones. Profiles are projected along N-S lines from ship's tracks shown in the index map. Hash marks at

slope, flanked on the seaward side by two deep lows centered near $2^{\circ} \mathrm{N}$., $46^{\circ} \mathrm{W}$. and $5^{\circ} \mathrm{N}$., $50^{\circ} \mathrm{W}$. The $1,000-$ and $2,000-\mathrm{fm}$ contours included in Figure 1 show the geometry of the cone. The Amazon cone and the fracture zones will both be considered in greater detai ${ }_{i}$ in later sections.

Along the base of the continental rise to the north of Brazil, there is a series of anomalies

\section{KILOMETERS}

either end of topography, free-air gravity, and magnetic anomaly profiles mark $4,00(1 \mathrm{~m}, 0$ mgal, and 0 gammas, respectively. No magnetic data are available from V2709. The equator is at $\mathbf{0 m}$ on the horizontal scale.

associated with the North Brazilian Ridge. This marginal ridge is a narrow, sinuous topographic and basement feature which parallels the coast for $1,300 \mathrm{~km}$ from $35^{\circ} \mathrm{W}$. until it disappears under the Amazon cone (Hayes and Ewing, 1969, 1970). Hayes and Ewing (1970) originally considered the ridge to be a continuous marginal ridge, citing its apparent continuity as evidence of a single mode of 

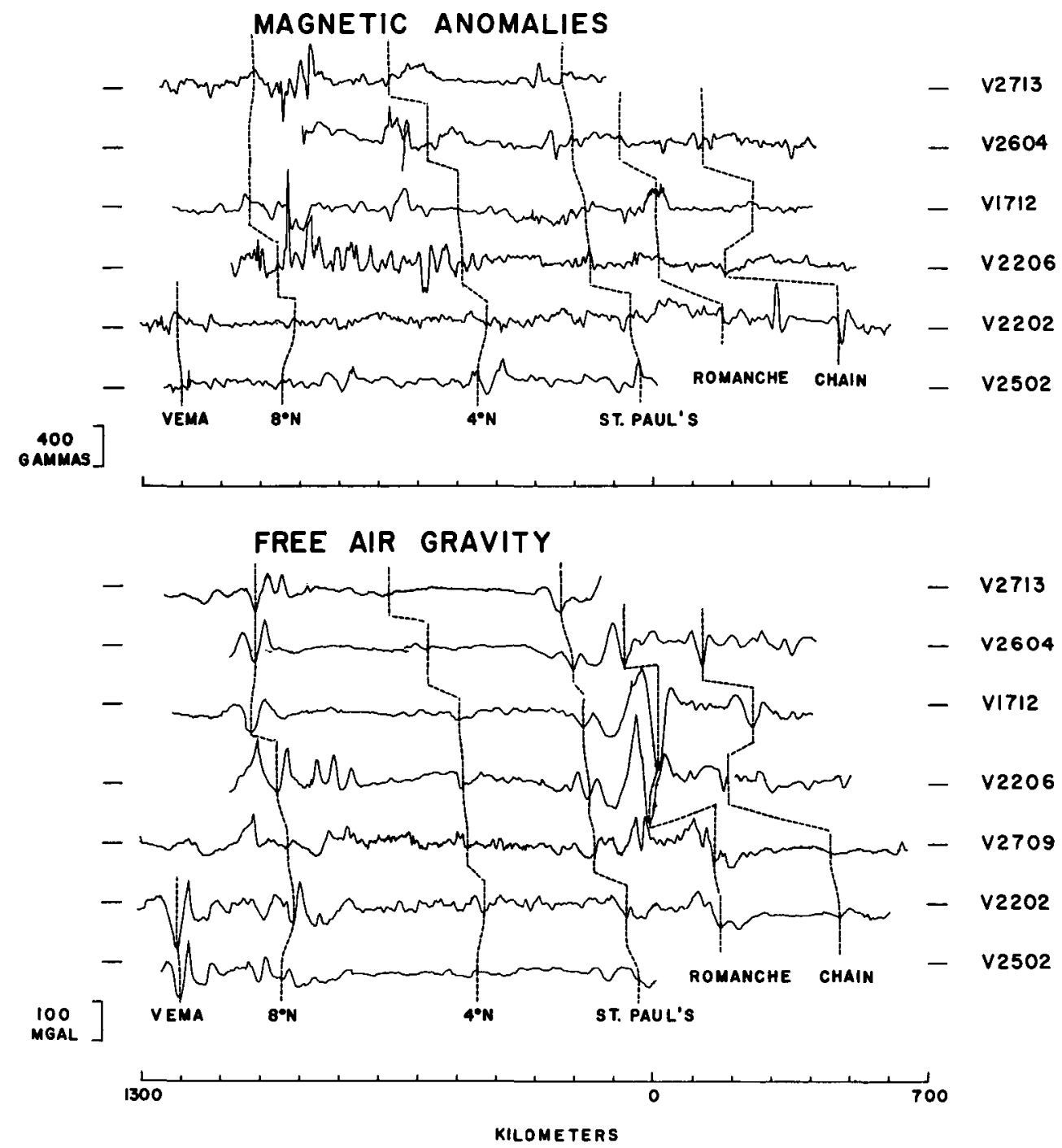

Figure 2. (continued).

formation. Le Pichon and Hayes (1971) later reinterpreted the ridge as consisting of two types of segments, one consisting of extensions of the oceanic fracture zones toward the continent and the other of marginal ridge segments offset by the fracture zones.

The southern half of the Guiana Basin contains numerous seamounts. They are characterized by sharp gravity maximums, usually flanked by a shallow ring of low gravity. This pattern is particularly evident on Figure 1 for the seamount just north of the St. Paul's fracture zone at $1.5^{\circ} \mathrm{N} ., 37.5^{\circ} \mathrm{W}$.
The gravimetric expression of the Ceara Rise is readily apparent between $41^{\circ} \mathrm{W}$. and $44^{\circ} \mathrm{W}$. along $4^{\circ} \mathrm{N}$. The rise consists of an eastwest segment parallel to the fracture-zone trends and a northwest-southeast segment. A gravity low of $-50 \mathrm{mgal}$ is at the base of the western escarpment bounding the rise, and anomalies reach values near $0 \mathrm{mgal}$ over the rise.

An east-west-trending region of very negative free-air anomalies stretches along the base of the continental rise from the Barbados Ridge to the Demerara Plateau and then con- 
tinues eastward across the basin to the flanks of the Mid-Atlantic Ridge, where it dies out near $45^{\circ} \mathrm{W}$. The trend of the region is shown by the -50 -mgal contour on Figure 1, which outlines the deepest part of the minimum. The area of very negative anomalies extends northward to about $11^{\circ} \mathrm{N}$. and is separated from the gravity minima at the base of the Amazon cone to the south by a relative gravity high of about $20 \mathrm{mgal}$. This low regional anomaly is not associated with any topographic feature. The thick blanket of Amazon sediments hinders observation of basement on profiler records in much of the basin, and so it is not possible to definitely state whether it is due to an anomalously great depth to basement between $7^{\circ} \mathrm{N}$. and $11^{\circ} \mathrm{N}$. or, as is considered more likely, is due to processes within the crust or mantle.

It is interesting to note that the regional gravity field is quite negative throughout the area. The regional anomaly varies from -15 to $-40 \mathrm{mgal}$ and positive free-air anomalies are found only on the Mid-Atlantic Ridge and over very strong topographic features. The regional anomaly is of the order of $-15 \mathrm{mgal}$ to the south of $5^{\circ} \mathrm{N}$. and to the north of about $11^{\circ} \mathrm{N}$. Its magnitude increases sharply to around $-40 \mathrm{mgal}$ in the intermediate area under the influence of the very negative region mentioned above. There also appears to be an east-west regional trend in the general level of the free-air anomalies, with the values becoming less negative on the Mid-Atlantic Ridge flanks in those areas not grossly disturbed by large fracture zones. The presence of a regional free-air anomaly high over the equatorial Mid-Atlantic Ridge is consistent with the observation that mid-ocean ridges generally show a free-air gravity high with respect to the basins flanking them (Kaula, 1972).

\section{Fracture Zones}

Fracture zones appear on the free-air gravity map as long, linear anomalies. Those apparent in Figure 1 are the Chain fracture zone at $4^{\circ} \mathrm{S}$., the Romanche at $1^{\circ} \mathrm{S}$., the St. Paul's at $1^{\circ} \mathrm{N}$., a complex between $2^{\circ} \mathrm{N}$. and $6^{\circ} \mathrm{N}$., the $8^{\circ} \mathrm{N}$. fracture zone and the Vema fracture zone at $11^{\circ} \mathrm{N}$. Topography, free-air gravity, and magnetic anomaly profiles of the equatorial fracture zones are presented in Figure 2. The locations of the profiles and the fracture zones are shown in the index map of Figure 2.
Distances along the ship's track do not necessarily correspond to distances on the profiles of Figure 2 since they have been projected along a north-south direction perpendicular to the general strike of the fracture zones.

It is evident that the gravity anomaly is probably the simplest meihod of identifying fracture zores. For example, the St. Paul's, Romanche, Chain sequence maintains a very characteristic gravity signature from profile to profile in spite of changes: in topography and magnetic anomalies. One s:eason for this fact is that the highly fractured nature of the equatorial Atlantic and the proximity to the magnetic equator combine to make the identification of sea-floor-spreading anomalies impossible. -n basins at higher latitudes, fracture zones are usually recognized by disruptions and offsets in the magnetic anomaly pattern.

The topographic expression of the: Chain fracture zone in the survey area is a chain of seamounts and islands, allowing the fracture zone to be traced by a linear series of positive anomalies aiong $4^{\circ} \mathrm{S}$. The westernmost seamount is at $36^{\circ} \mathrm{W}$. As noted by Francheteau and Le Pichon (1972), a continuation of this line would be parallel to the trend of the Rio Grande do Norte sedimentary basin.

The Romanche fracture zone can be traced to $36^{\circ} \mathrm{W}$. as a continuous ridge of positive freeair anomalies. The topographic expression of the fracture zone in the survey area is a double peaked northern ridge, a trough, and a usually lower southern ridge (see Fig. 2, V27(19). The southern ridge is completely buried in sediments west of $31^{\circ} \mathrm{W}$, and the lower of the two northern peaks is buried sy $33^{\circ} \mathrm{W}$., causing an apparent change in trend of the fracture zone (Hayes and Ewing, 1970). The Romanche fracture zone is completely buried west of $35^{\circ} \mathrm{W}$. The gravity anomalies, however, continue to refiect the basement topography and correct trend of the fracture zone. There is a difference in the general level of the gravity field on either side of the Romanche fracture zone due to the great difference in the age of the crust. This is most noticeable on profiles V2202 and V2709 on Figure 2, which go from a ridge flank province on the north side to an abyssal plain province on the southern side.

Le Pichon and Hayes (1971) have developed a model of the early opening of the South Atlantic in which the Romanche and St. Paul's fracture zones extend to offsets in the con- 
tinental margin as segments of the North Brazilian Ridge. The section of the North Brazilian Ridge to the east of $37^{\circ} \mathrm{W}$. coincides with the linear 0 -mgal contour at $1.8^{\circ} \mathrm{S}$. on Figure 1 and can be traced on seismic profiler records eastward to at least $34^{\circ} \mathrm{W}$. It thus parallels the Romanche fracture zone for $300 \mathrm{~km}$ at approximately $30 \mathrm{~km}$ to the south of the fracture zone, to which it appears intimately related.

The North Brazilian Ridge turns to the north at $37^{\circ} \mathrm{W}$., entering into a "marginal ridge" segment. This region is characterized by numerous seamounts; indeed, the ridge may consist of a series of seamounts rather than a continuous basement feature as is found farther to the east. A particularly prominent cluster of seamounts sits to the south and west of this segment of the ridge. The fracture zone likely continues to the continental margin through these seamounts and as the seaward edge of a wedge-shaped terrace which lies just to the west of them at a depth of 2,500 $\mathrm{m}$ in an otherwise steep continental rise.

The St. Paul's fracture zone is characterized by a positive free-air anomaly with a width of $75 \mathrm{~km}$ and a magnitude of 50 to $70 \mathrm{mgal}$ above the regional field in the basin, flanked to the south by a narrow low over a sedimentfilled trough. The fracture zone may be traced continuously to a very prominent seamount at $39^{\circ} \mathrm{W}$. There is another seamount at $41^{\circ} \mathrm{W}$. roughly along the east-west trend of the fracture zone along latitude $1^{\circ} \mathrm{N}$., and a gravity high at $43^{\circ} \mathrm{W}$. also along this trend. This data would suggest that the fracture zone continues to the west along $1^{\circ} \mathrm{N}$.

An alternative suggestion has been made by Le Pichon and Hayes who consider that the east-west part of the North Brazilian Ridge at $0^{\circ}$ continues into the St. Paul's fracture zone in a manner analogous to the continuation of the St. Paul's fracture zone into the African margin through marginal ridges. From the available data, the westward continuation of the St. Paul's fracture zone is still open to question.

For most of its length, the topographic expression of the east-west segment of the North Brazilian Ridge (between $40^{\circ}$ and $45^{\circ}$ W.) does not coincide with the peak of a relative gravity maximum, but rather is on the southern flank of the gravity feature. This is illustrated in Figure 3 which shows projected topography, magnetic, and free-air gravity profiles for eight crossings of this portion of the ridge. The arrow on each gravity and magnetic profile shows the location of the topographic expression of the ridge. The reason for the displacement of the gravity peak from the topographic peak is not clear. However, this displacement does indicate the presence of a complicated buried structure.

There is a sharp change in the character of the North Brazilian Ridge at $41.5^{\circ} \mathrm{W}$. The eastern part of the east-west segment of the ridge, represented by profiles $A$ and $B$ of Figure 3 , is characterized by a very steep peak which reaches to within $60 \mathrm{fm}$ of the surface on one sounding. The gravity anomalies over this section are very large, reaching more than +100 mgal and are directly related to the topography. To the west of $41.5^{\circ} \mathrm{W}$., the ridge is much more subdued, never being any shallower than $3,000 \mathrm{~m}$ and is in many places buried under sediments at slightly more than $4,000 \mathrm{~m}$. The gravity anomalies over the topographic ridge are small and are superimposed on the flank of a large relative maximum to the north of the ridge as mentioned above.

It can also be noted from the profiles and from Figure 1 that the gravity anomalies are more negative on the landward side of the ridge than in the abyssal plain to the north. This is suggestive of a major difference in the depth to basement or in the character of the basement on either side of the North Brazilian Ridge. Seismic refraction (sonobuoy) profiles also indicate that the sediment layer is at least 1.0 to $2.0 \mathrm{~km}$ thicker on the landward side of the ridge than on the seaward side (Bryan and others, 1973).

There are several identifiable small fracture zones between $2^{\circ} \mathrm{N}$. and $7^{\circ} \mathrm{N}$. (a fracture zone being defined by a sediment-filled trough). It is unlikely that they are all currently active. The offset of the Mid-Atlantic Ridge in this region is small and occurs mainly at $4^{\circ} \mathrm{N}$. where the light seismic activity on the ridge is concentrated. The topographic high associated with the $4^{\circ} \mathrm{N}$. fracture zone can be traced as both a topographic and gravity feature as far as $39^{\circ} \mathrm{W}$. and probably continues to form the backbone of the east-west portion of the Ceara Rise. Magnetic and gravity data collected on Conrad Cruise 13 for a JOIDES site survey on the Ceara Rise suggest the presence of an eastwest-trending basement ridge under the rise (Embley and others, 1972). 
TOPOGRAPHY
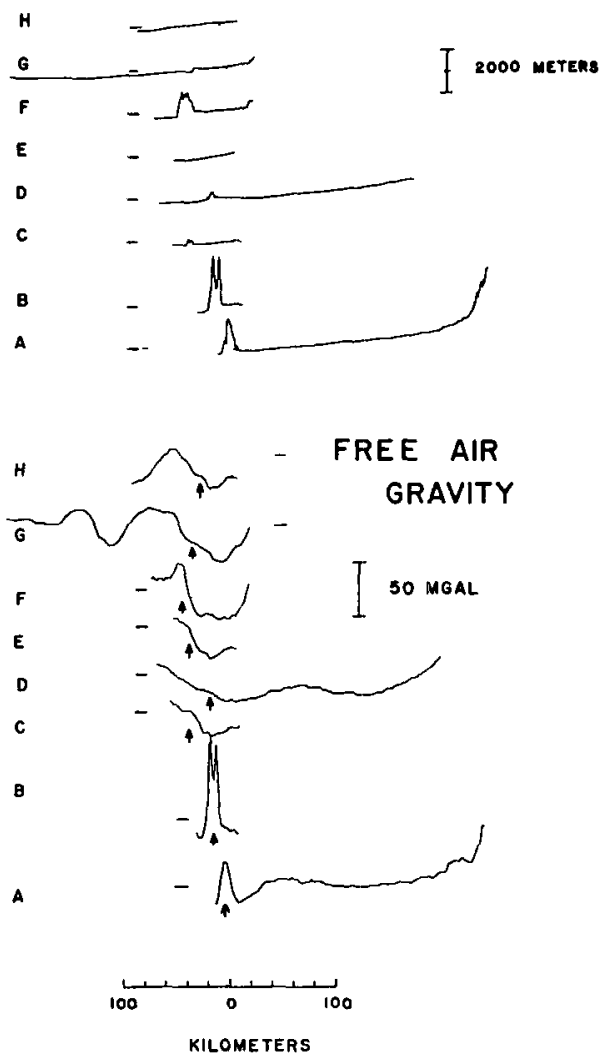

Figure 3. Projected topography, free-air gravity, and magnetic anomaly profiles across the east-west portion of the North Brazilian Ridge. Index map shows location of ship's tracks. The hash marks on the topography, gravity, and magnetic anomaly profiles mark 4,000 m, - $-25 \mathrm{mgal}$, and 0 gammas, respectively. Profiles are projected north-south, and the equator is at $0 \mathrm{~km}$ on the horizontal scale. Arrows on gravity and

The $8^{\circ} \mathrm{N}$. fracture zone is a major feature which has received very little attention in the literature (Heezen and others, 1969). It is characterized by a trough between rather steep ridges and offsets the crest of the Mid-Atlantic Ridge by 6 degrees of longitude, more than twice the offset at the Vema Fracture Zone just to the north. The data are rather sparse in this area, but it can be seen that at $40^{\circ} \mathrm{W}$., as one moves away from the Mid-Atlantic Ridge crest, the trough rapidly fills with sediments, greatly reducing the magnitude of the negative portion of the free-air anomaly.
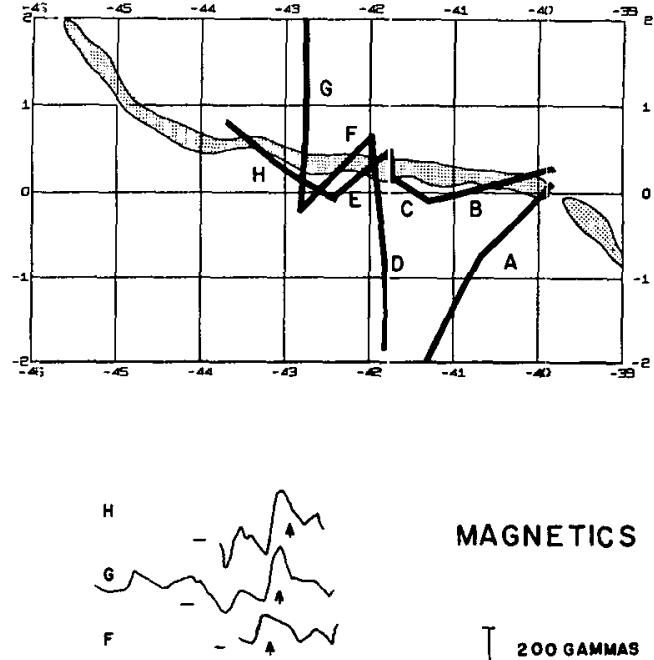

MAGNETICS

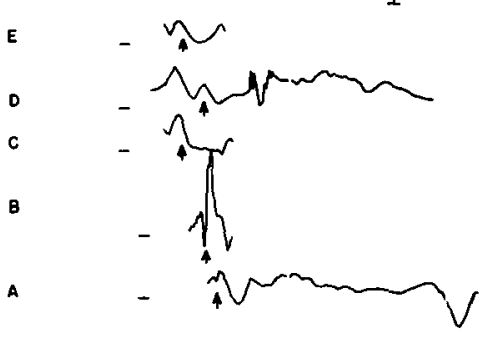

$$
\begin{aligned}
& 100 \text { L L } \frac{1}{0}+100 \\
& \text { KILOMETER! }
\end{aligned}
$$

magnetic anomaly profiles mark location of topographic or basement expression of the ridge. Note that although there is a magnetic anomaly associated with the ridge, the gravity maximum sits to the north on profiles $C$ through $\mathrm{H}$. The change in the character of the ridge at $41.5^{\circ}$ is apparent in the difference between profiles B and $\mathrm{C}$.

There is no evidence, eitiner topographic or gravity, of the $8^{\circ} \mathrm{N}$. fractire zone to the west of the Demerara Abyssal Plain. This is rather surprising, since, as can be seen in Figure 2, it is a major feature of the eastern basin and can be easily traced nearly to the African continental margin (Heezen ar.d others, 1969).

The axial section of the Vema fracture zone is clearly visible at $11^{\circ} \mathrm{N}$. in Figure 1. Beyond the deeply rifted central portion, the fracture zone changes trend and can be traced as a broad negative anomaly to $48.5^{\circ} \mathrm{W}$. ".."There is no evidence of its continuction farther to the 
west. The Vema fracture zone fits very well flow lines predicted from the North Atlantic poles of rotation (Pitman and Talwani, 1972). The change in trend occurs at the time of anomaly 5 (9 m.y. B.P.) and the "disappearance" of the fracture zone at anomaly 13 (38 m.y. B. P.).

The series of linear negative gravity anomalies immediately south of the Vema Fracture Zone are the expressions of troughs associated with several aseismic, relict fracture zones which parallel the trend of the Vema fracture zone (van Andel and others, 1967) from anomaly 13 to anomaly 5 time.

\section{Magnetic and Gravity Profiles over Fracture Zones}

The available data include many crossings of the equatorial fracture zones nearly perpendicular to their strike. Topography, magnetic anomalies, and free-air gravity anomalies were projected along north-south lines normal to the general strike of the faults to assist in examining the properties of the fracture zone.

The most striking feature of the magnetic anomaly profiles is the presence of a sharp positive peak with a magnitude of 200 to 300 gammas and a width of $20 \mathrm{~km}$ offset from the topographic and gravity highs by about 30 $\mathrm{km}$ so as to be over the trough of the fracture zone (Fig. 4). This anomaly is particularly well developed over the Romanche and St. Paul's fracture zones and is not an edge effect between areas of opposing magnetization on either side of the fracture zone. This was verified by actual calculation; in that case, a step results instead of a peak. There was only one profile for which the magnetic anomalies could be explained in this manner. That was a crossing of the St. Paul's fracture zone which will be mentioned again below in relation to its gravity anomalies.

Van Andel has noted this magnetic spike at fracture zones in the equatorial Atlantic and ascribed it to highly magnetized serpentine intrusions in the trough (Vogt and others, 1971). Olivet and others (1973), on the other hand, report that magnetic-anomaly patterns die out within $30 \mathrm{mi}$ of the Gibbs fracture zone in the North Atlantic. Matthews and others (1965) noted the same phenomenon in the Indian Ocean, which they explained by expunging of the magnetization by extensive brecciation and hydrothermal alteration of the crustal rocks by shearing within the fault zone.
It is unlikely that the magnetic anomaly spike is due to an isolated zone of serpentine intrusion. The often made statement that serpentinized rocks are highly magnetic is only partly true. Serpentinite does have a high susceptibility, but it also has a much smaller remanent magnetization than oceanic basalt. The NRM intensity of serpentinite dredged from the Mid-Atlantic Ridge is nearly an order of magnitude less than that of the basalt making up the standard oceanic basement (Opdyke and Hekinian, 1967; Miyashiro and others, 1971). In fact, Opdyke and Hekinian, in discussing dredge hauls of spilitized basalt, amphibolite, serpentinite, and chloritic rocks, concluded that "these rocks would probably appear nonmagnetic to a towed proton-precession magnetometer" (Opdyke and Hekinian, 1967, p. 2259).

The opposite hypothesis to a zone of highly magnetized rocks is that the spike is caused by an area of zero magnetization, either because the trough cuts through the magnetized layer or because the magnetization of the rocks in the area of the trough was destroyed by intense shearing. A model consisting of two semiinfinite magnetized blocks separated by a $20-$ $\mathrm{km}$ nonmagnetized zone representing the fracture-zone trough will produce a positive spike of approximately the observed amplitude if both sides are normally magnetized, but also a negative spike if both are reversely magnetized, and two smaller peaks of opposite signs if normal on one side and reversed on the other. These results hold for rocks magnetized at this location in the direction of any Earth's field since Early Cretaceous time.

There are twelve crossings of the Romanche fracture zone fairly evenly spaced between $30^{\circ} \mathrm{W}$. and $35^{\circ} \mathrm{W}$. In each case, the magnetic spike is positive (Fig. 4). It is difficult to imagine that the basement along the fracture zone on both sides of the fault is normally magnetized for a distance of $500 \mathrm{~km}$.

If the observed anomaly is due to an area of zero magnetization in the fracture zone trough, then the implication is that the magnetization of the fracture-zone rocks is induced in nature or, if remanent, has a strong viscous (VRM) component in the direction of the present Earth's field. Ultrabasic and metamorphic rocks in general not only have low magnetizations, but they also have high susceptibilities, giving them very low $Q^{\prime}{ }_{n}$ values. The value of $Q^{\prime}{ }_{n}$ reported for serpentinite by Opdyke and 


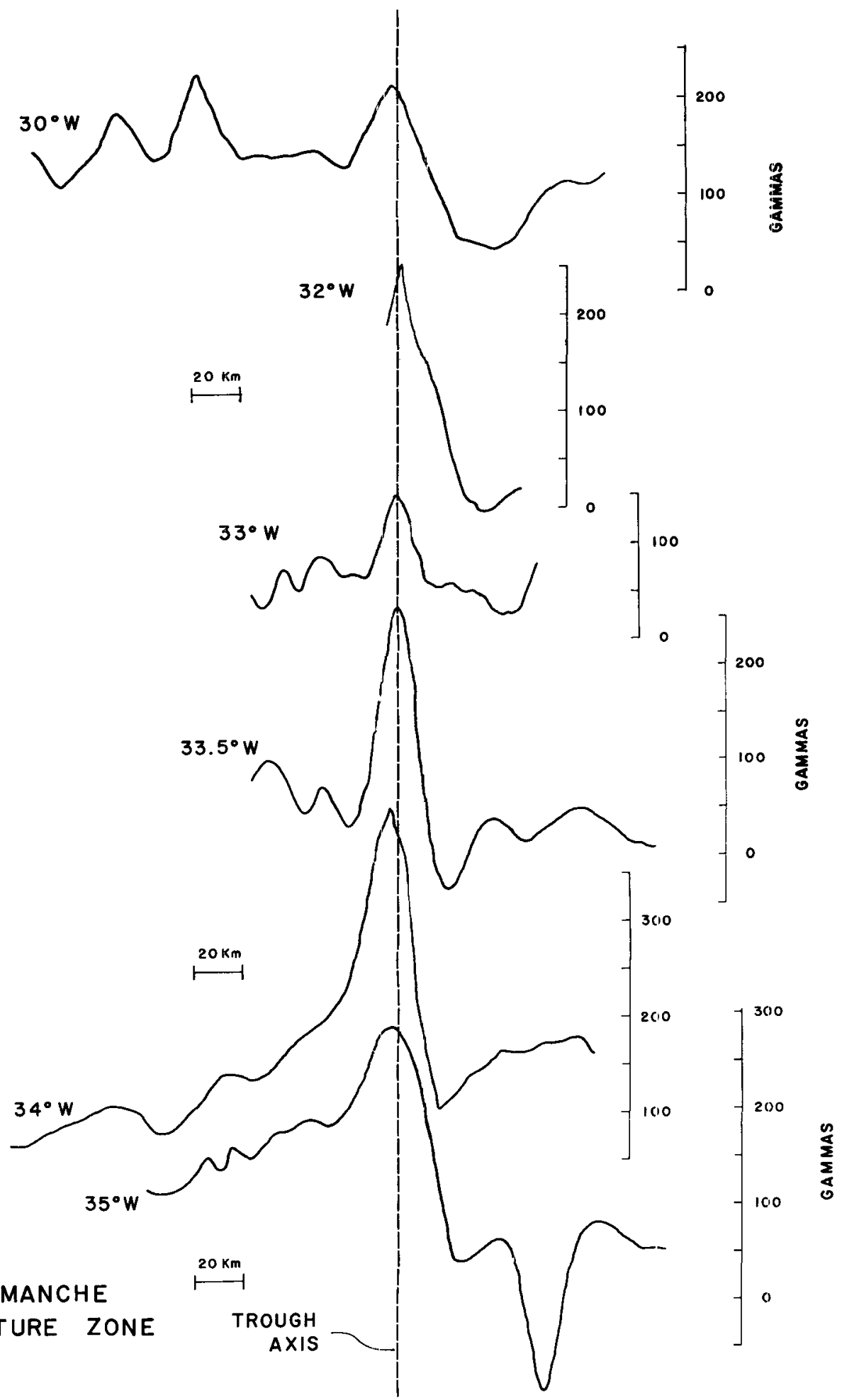

Figure 4. Projected magnetic anomaly profiles over the Romanche fracture zone illustrating sharp positive peaks over the fracture-zone trough. Profile at $34^{\circ} \mathrm{W}$. is $\mathrm{DD}^{\prime}$ used in gravity model shown in ligure 6 . 
Hekinian (1967) is 0.60 , implying the presence of a large induced component and that the remanent magnetization is likely to be soft. Figure 5 shows the magnetic anomalies generated by a large intrusion of ultrabasic rocks. The shape and size of the body were made compatible to the gravity body deduced below. The susceptibility used was .00385 emu per cc and the body was also given a small remanent magnetization of .0015 emu per cc along the Earth's field to conform with observed remanent magnetizations of serpentinized rocks from the Mid-Atlantic Ridge (Opdyke and Hekinian, 1967). Since this remanent magnetization is along the Earth's field, the effect of not including it would be to reduce the magnitude of the anomaly. It is valid to put the NRM along the Earth's field, although the age of the basement is not known since this area has been within 10 degrees of the equator since Triassic time (Creer, 1970).

The analysis of the magnetic anomalies is made much simpler by the proximity of the fracture zones to the equator. One reason is that the magnetic anomaly field is much more quiet than in higher latitudes, causing the anomaly associated with the fracture zone troughs to stand out. Also, the anomaly, which is actually the superposition of two edge-effect anomalies, is symmetric and easily recognizable.
As one moves away from the equator, the anomaly rapidly becomes skewed and difficult to recognize.

There is, however, evidence from locations other than the equatorial Atlantic that the magnetization of large fracture zones is induced rather than remanent. Talwani and Eldholm (1973) discuss a linear anomaly off the coast of South Africa associated with the Agulhas fracture zone, which they interpret as marking the boundary between oceanic and continental crust. In every crossing of the Agulhas fracture zone, the anomaly shows the same polarity and can be reproduced by a model of the anomaly caused by the edge of a plate magnetized by induction in the Earth's present field.

A series of two-dimensional Bouguer anomalies were calculated for the fracture zone profiles by the method of Talwani and others (1959). It was found that, for all reasonable densities, the Bouguer anomaly curves still exhibited a relative maximum over the fracture zones with magnitudes of 25 to $30 \mathrm{mgal}$, or approximately one-half those of the free-air anomalies.

The single exception to this pattern was the crossing of the St. Paul's fracture zone near $37^{\circ} \mathrm{W}$. mentioned above with respect to its magnetic anomaly. In this case, making the
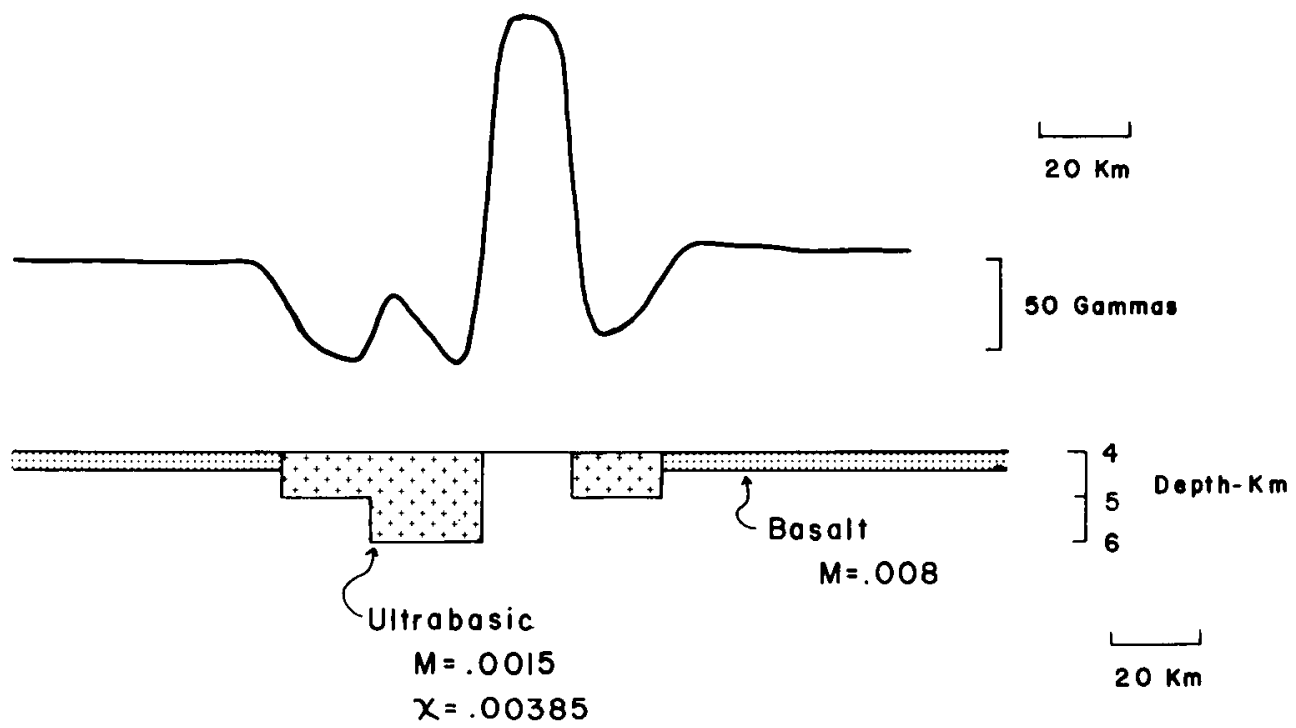

Figure 5. Magnetic anomaly pattern resulting from an intrusive body of ultrabasic rocks. The magnetization in the immediate area of the trough is considered to have been destroyed by intense shearing. Note the presence of a large peak over the trough. 
Bouguer corrections for the water and sediment layers resulted in a smooth, flat curve.

In order to account for the observed gravity anomalies, it is necessary to introduce additional mass into the area under the fracture zone ridge and trough. The curve labelecl "isostatic model" in Figure 6 represents the free-air anomaly obtained from compensating the basement topography and sediments. It is the difference between this and the observed anomaly which must be explained in terms of departures from simple Airy isostatic compensation. Figure 6 shows the observed and computed free-air anomalies for a typical Romanche fracture zone profile in which this is accomplished by replacing layer 2 by a body with a density contrast of +0.3 in the area beneath the fracture zone.

Serpentine is an alteration product of olivine formed by hydration at low temperatures. Reported densities and susceptibilities of rocks described as "serpentinite" vary over nearly the entire range of values found in nature. Hatherton (1967) present; a plot of density and magnecic susceptibili:y for dunites and serpentinized dunites from the Cook Strait region of New Zealand. As the amount of serpentine increases, the density decreases from 3.3 to $2.5 \mathrm{~g}$ per $\mathrm{cm}^{3}$ and the susceptibility increases two orders of magnitude from $10^{-4}$ to $10^{-2}$ emu per $\mathrm{cm}^{3}$. The combination of $2.9 \mathrm{~g}$ per $\mathrm{cm}^{3}$ anc $.00385 \mathrm{emu}$ per $\mathrm{cm}^{3}$ used here are consistent with Hatherton's data as well as with dredge hauls from fracture zones.

This solution is, of course, not unique. Another solution could have been found, for instance, by modeling the crust as thinner beneath a fracture zone and raising the Moho in a suitable manner. However, the close correlation between the gravity anomaly and basement topography together with the magnetic evidence suggesting both the presence
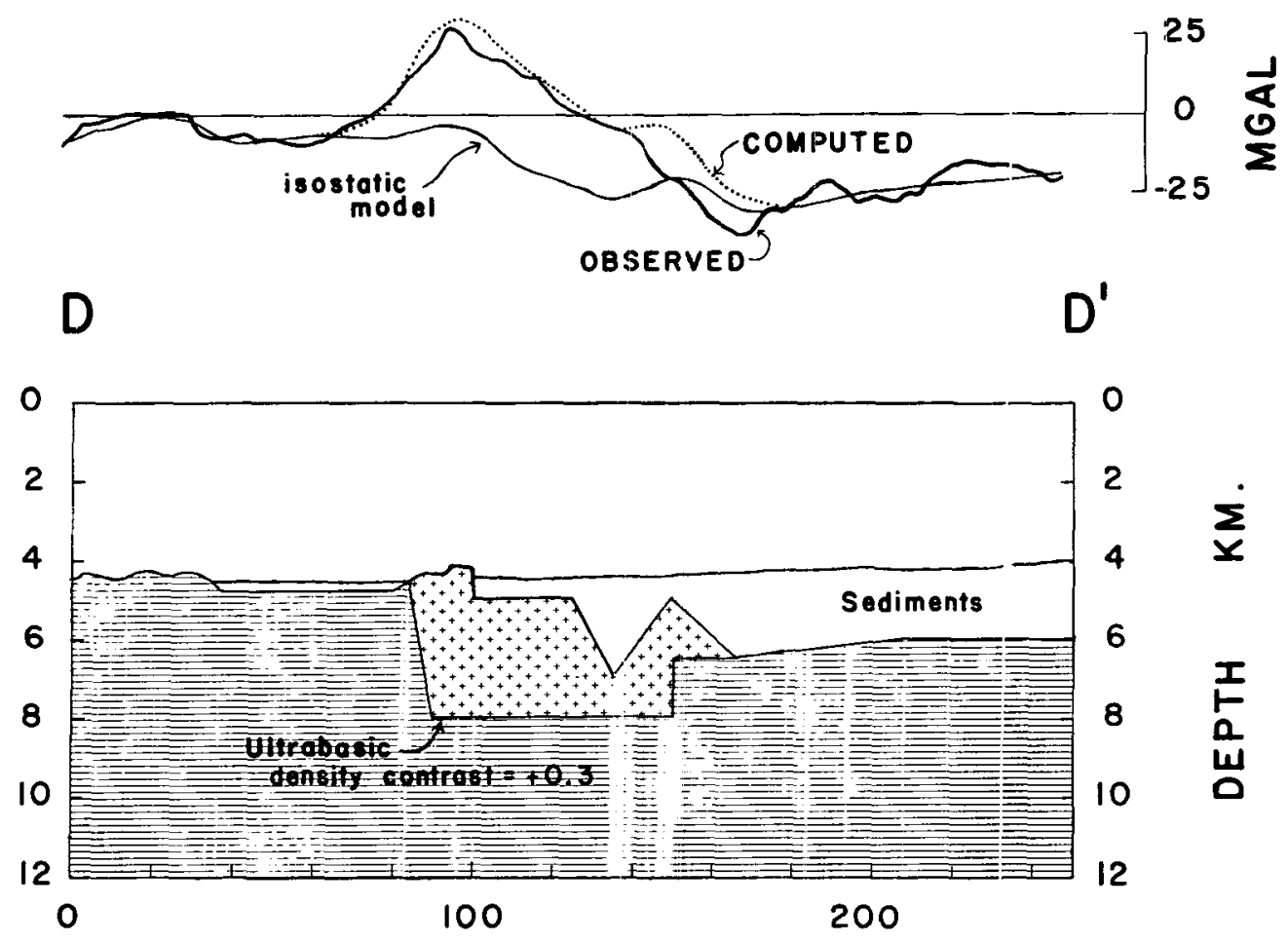

\section{KILOMETERS}

Figure 6. Gravity profile across Romanche fracture: zone at $34^{\circ} \mathrm{W}$. The curve labeled "isostatic model" is the computed gravity effect of variations in the thick. ness of the water and sediment layers and their com. pensation using an Airy model. The computed curve shown by a dotted line is the sum of the "isostatic model" and the gravity effect of the body labeled "ultrabasic" which represenrs the area around the fracture zone into which a body of ultrabasic rock has been emplaced. 
of ultramafic rock and the absence of highly magnetic basalt favors an upper crustal source for the required mass excess.

Serpentinite and serpentinized peridotite is a frequent constituent of dredge hauls from the mid-oceanic ridge system in both the Atlantic (Shand, 1949; Nicholls and others, 1964; Bonatti, 1968; Miyashiro and others, 1969; Melson and Thompson, 1971) and Indian Oceans (Cann and Vine, 1966; Hekinian, 1968). Aumento and Loubat (1971) point out that, with a few exceptions, all samples of serpentinized ultramafic rocks dredged from the ocean floor were recovered from transverse fracture zones and areas of the mid-oceanic ridge adjacent to fracture zones. Thompson and Melson (1972) report that detailed studies of the petrology of fracture-zone peridotites indicate that "many are unrelated to the basalts of the volcanic zone, that is they are not crystal accumulates from the overlying basalt, but are probably derived from the upper mantle" (Thompson and Melson, 1972, p. 534).

The nature of fracture zones, as suggested by Figure 6 and the above discussion, is somewhat different from models suggested by Miyashiro and others (1969), Bonatti and others (1971), and Melson and Thompson (1971). In their models, although intrusions of serpentinized peridotite might make up the floor of the trough, fracture zones basically provide a window into the lower crust, the nature of which can be examined where it outcrops on the sides of the trough. The geophysical evidence presented here, along with published petrological studies suggest, on the other hand, that large fracture-zone offsets of the mid-ocean ridges serve as sites of largescale intrusion, so that the upper crust consists mainly of dense ultramafic rocks for a distance of 20 to $30 \mathrm{~km}$ from the center of a large fracture zone. This does not imply that basaltic rocks are completely absent in the area of a fracture zone. Indeed, some must be present, as dredge hauls from fracture-zone escarpments do yield some basaltic rocks.

\section{Amazon Cone: Flexural Rigidity and Deformation of the Lithosphere}

The great mass of sediments and determination of the pattern of gravity anomalies associated with the Amazon cone present an opportunity to determine the deformation caused by this load and thus the value of the flexural rigidity of the lithosphere and the bending stresses imposed on the lithosphere in this region.

The flexural rigidity of an elastic beam, defined as $E I$, where $E$ is Young's Modulus and $I$ is the moment of inertia of the cross section with respect to the neutral axis, is a measure of the resistance of the beam to deformation by a bending couple (Timoshenko, 1956, p. 95). With the current model of rigid lithospheric plates, it is actually a more relevant parameter than the ultimate strength in determining the response of the lithosphere to an imposed system of stresses, since it determines the manner and extent to which an imposed load will be supported-and thus the stress distribution and the possibility of elastic failure. From the point of view of isostasy, the flexural rigidity will determine the extent to which the lithosphere supports a given load, and thus the area over which compensation for the load is distributed.

The loading of elastic beams is a well-studied engineering problem and is treated, for example, in Timoshenko (1956). The radius of curvature $r$ of a deformed beam is given by:

$$
\stackrel{l}{r}=\frac{M}{E l}=\frac{M}{D}
$$

where the denominator $E I$ is equal to the flexural rigidity $D$, and $M$ is the bending moment, which is defined as the algebraic sum of the moments of the external forces to one side of the cross section at which the deformation is to be calculated with respect to the centroid of the cross section. Since $1 / r$ may be approximated by $d^{2} y / d x^{2}$ and the bending moment determined by the geometry of the problem, the deformation may be determined.

When one is discussing the lithosphere, it is difficult to determine the bending moment directly, as it is defined in terms of the distance from a fixed support. However, its second derivative, the restoring stress, may be expressed in terms of known quantities (Gunn, 1943). We thus must differentiate the above equation twice, obtaining a fourth-order differential equation for the deformation, which gives physical solutions in the form of damped sinusoids. The relevant boundary condition is that the deformation goes to zero at infinity. Gunn $(1943,1944)$ and Vening Meinesz (1948) first applied elastic beam theory to geological problems to determine the stresses and deformation resulting from loading of the lithosphere and solved the result- 
ing differential equations for several two- and three-dimensional loads. Walcott used threedimensional models to deduce a value of $2 \times$ $10^{23} \mathrm{nt} \mathrm{m}\left(2 \times 10^{30} \mathrm{dyne}\right.$ per $\left.\mathrm{cm}\right)$ for the flexural rigidity of oceanic lithosphere from the Hawaiian ridge (Walcott, 1970a) and somewhat larger values for continental lithosphere, mainly from the deformation caused by Pleistocene lakes and ice sheets (Walcutt, 1970b).

The model adopted for this study is a twodimensional model similar to that adopted by Walcott (1972) for a continental margin consisting of a load of sedimentary rock with a density of 2.45 replacing water with a density of 1.03 overlying the lithosphere, which in tirn floats on an asthenosphere of density 3.3 which is considered to have negligible long-term strength. The continental margin is considered to have been in isostatic equilibrium before deposition of the load, and any depression resulting from the load is considered to be filled with sediments of density 2.45. The value of $2.45 \mathrm{~g}$ per $\mathrm{cm}^{3}$ for the density of the sediment load is the average density of the entire sediment load, including consolidated and unconsolidated sediments, as inferred from seismic velocity data on the cone.

The internal structure of the lithosphere does not affect the calculation of the deformattion as long as it may be treated as an elastic plate with an effective rigidity. Further, neither the density nor the thickness of the lithosphere enters directly into the calculations. Indeed, since the lower boundary is probably gradational, it would be difficult to assign a specific thickness to the lithosphere, although an "effective" thickness may be determined from its response to the load if one is willing to assume values for the elastic parameters of the lithosphere.

The geometry of the load was determined by projecting topographic and gravity profiles: perpendicular to the trend of the topography. The top of the lithosphere prior to the deformation was taken to be an oceanic basin at a depth of $5 \mathrm{~km}$ below sea level, rising to sea level at the continental shelf. The transition was assumed to occur in a distance of $200 \mathrm{~km}$ and was centered at the seaward edge of a pattern of short wave-length gravity and magnetic anomalies observed on the shelf (Fig. 7).

Because the two ship's tracks suitable for projection were over steeper sections of the cone and passed through the two deep gravity minima, a third profile was constructed running down the center of the cone about midway between the otier two profiles. The topography was taken from U.S. Navy Hydrographic Office charts and the gravity anomalies from Figure 1. The three profiles are shown in Figure 7 , along with the geometric rendering of them used in the calculations. Their locations are shown in Figure 1.

The gravity anomalies were calculated by assuming that the Moho and entire crustal structure were depressed by the amount of deformation and free-air anomalies, and comwere then calculated by the method of Talwani and others (1959). The post-deformation sections are not in isostatic equilibrium in the sense of having equal mass above the compensatior. level at all pcints, but rather are in what Gunn called "isobaric" equilibrium since the total pressure at the depth of compensation is the same at all points. Thus botk. the effect of the mass and of any vertical stress resulting from the loading are taken into account. This is equivalent to saying that: the area is in regional isostatic equilibrium.

The flexural rigidity was determined by assuming a value, calculating the resulting deformation and free-air: anomalies, and comparing them to the observed anomaly pattern. The value which gives the best fit for the three profiles is $2 \times 10^{23} \mathrm{nt} \mathrm{m}\left(2 \times 10^{30}\right.$ dyne per $\mathrm{cm}$ ). This value is the same as the value obtained by Walcott $(1970 \mathrm{a}, 1970 \mathrm{~b})$ in other areas and appears to be a good estimate of the flexural rigidity of oceanic lithosphere subjected to long-term loading. The precision of this estimate is about one-half an order of magnitude in that the rigidity is certainly less than $5 \times 10^{23} \mathrm{nt} \mathrm{m}$ and probably greater than $1 \times$ $10^{23} \mathrm{nt} \mathrm{m}$.

The deformed surface of the lithosphere and the observed and calculated free-air gravity anomalies are shown in Fiçure 7. The maximum deformation of the lithosphere is more than 6 $\mathrm{km}$, resulting in a maximum sediment thickness of 11 to $12 \mathrm{~km}$, which agrees well with seismic refraction results in the area (Edgar and Ewing, 1968).

This approach will, in general, give a gravity maximum over the area of thickest sediment, as is observed for the Amazon cone. Most sedimentary basins are, however, characterized by: a gravity minimum, wich must be due to the different role of the: sediments in the formation of the basin. In the case of a cone or 
PREDEPOSITION MARGIN
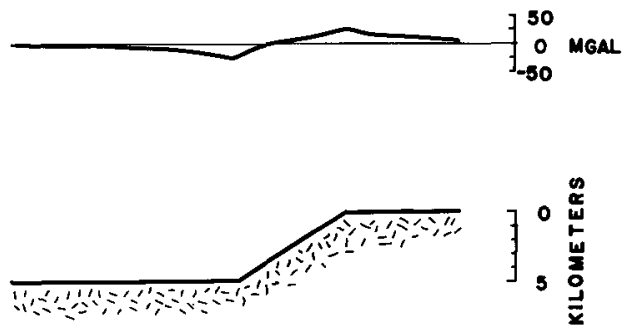

$100 \mathrm{~km}$
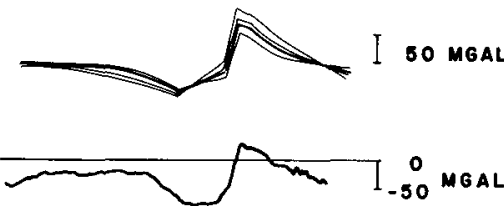

B

$B^{\prime}$
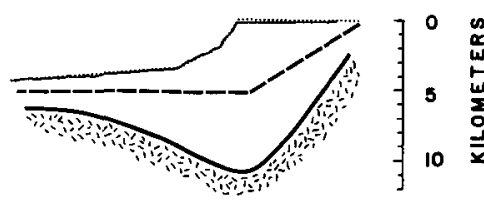

\section{$100 \mathrm{KM}$}

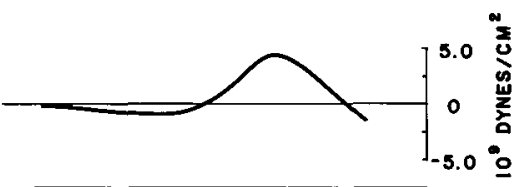

Figure 7. Gravity anomalies, deformation and bending stresses resulting from Amazon cone sediment load. The deformation and bending stresses are shown for a Hexural rigidity of $2 \times 10^{30}$ dyne $\mathrm{cm}$ and the gravity anomalies for $1,2,5$, and $10 \times 10^{30}$ dyne cm. The heavier curve of the calculated free-air anomalies is for $2 \times 10^{30}$ dyne $\mathrm{cm}$ which gives the best over-all fit to the observed gravity anomaly. The edge effect expected at an undeformed, compensated margin
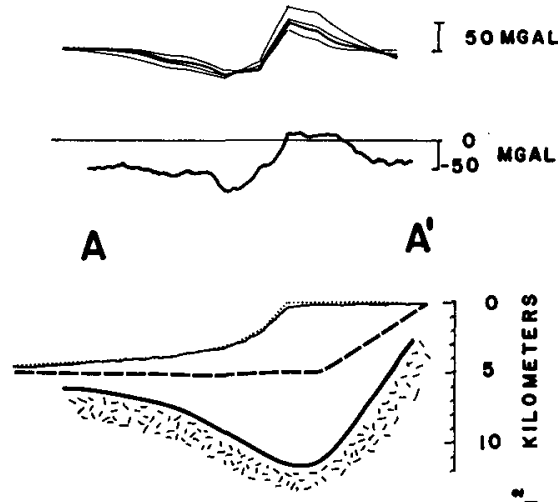

告

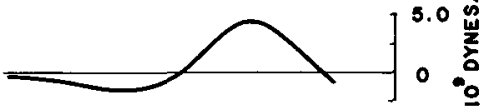

$100 \mathrm{~K}$

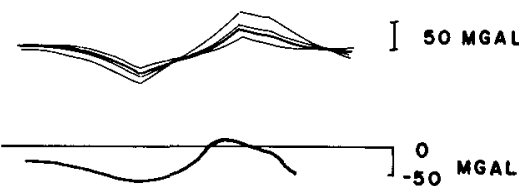

C

$C^{\prime}$
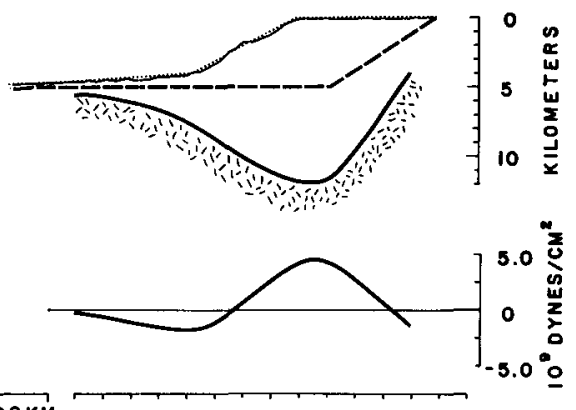

100KM

is shown in the predeposition margin figure. The observed bathymetry is shown by a solid line and that used in the computations by a dotted line. The dashed line shows the top of the lithosphere prior to deformation by the load of sediments. The heavy solid line gives the postdeformation position of the sediment-lithosphere boundary. The maximum deformation is slightly more than $6 \mathrm{~km}$, giving a maximum sediment thickness of between 11 and $12 \mathrm{~km}$. 
delta, the sediments are being deposited on a stable ocean bottom and serve as an active agent of deformation. In most basins, however, the sediments passively fill the depression caused by vertical motions of some other origin, and the positive effect of the sedimerts on the gravity is superimposed on the gravity effect of the agent of the vertical motion, which generally results in a gravity minimum.

The bending stress at a point on a loaded beam is given by

$$
S=\frac{M C}{I}
$$

where $I$ is the cross-sectional moment of inertia, $M$ is the bending moment at that point, and $C$ is the distance from the neutral axis to the point at which the stress is to be calculated, or half the thickness of the lithosphere. Since, as was mentioned before, the bending moment is very nearly equal to

$$
\text { EI } \frac{d^{2} y}{d x^{2}},
$$

the bending stress may be expressed as

$$
S=E C \frac{d^{2} y}{d x^{2}}
$$

and may be calculated, once the deformation is known.

The relative magnitude of the bending stresses is determined once the deformation is known. The absolute magnitude depends on the choice of a thickness for the lithosphere. The cross-sectional moment of inertia $I$ for unit width is given by $T^{3} / 12\left(1-\sigma^{2}\right)$, where $T$ is the thickness of the lithosphere and $\sigma$ is Poisson's ratio. With $\left(1-\sigma^{2}\right)=1$, the thickness $T$ is thus

$$
3 \sqrt{\frac{12 D}{E}}
$$

Taking $E=10^{12}$ dyne $\mathrm{cm}^{2}$ and $D=2 \times 10^{30}$ dyne per $\mathrm{cm}$ gives $29 \mathrm{~km}$ for the thickness of oceanic lithosphere.

If a value of $29 \mathrm{~km}$ is accepted for the effective thickness of the lithosphere plate, this implies that a maximum bending stress of 4.5 $\times 10^{9}$ dyne per $\mathrm{cm}^{2}$ would occur about $25 \mathrm{~km}$ inland from the shelf edge. The sense of the stress is that the base of the lithosphere is under tension and the surface under compression. There are two lesser stress maxima of opposite sign flanking the main maximum. They are of a magnitude of roughly $1.3 \times 10^{9}$ dyne per $\mathrm{cm}^{2}$.
It is unlikely that stress differences of this magnitude are actually present or could be supported in the lithosphere. The large magnitude calculated for the bending stress is probably the result of applying elastic beam theory to the Earth. The distribution of stresses is probably close to that shown in Figure 7 although the magnitude is undoubtedly much less.

Walcott (1970b) has proposed that the lithosphere behaves as a Maxwell, or viscous liquid, material with a relaxation time constant of $10^{5} \mathrm{yr}$. Thus, the lithosphere would behave in an elastic manner to a considerable depth in response to a short-time phenomenon such as the passage of seismic waves but would show a continually decreasing effective rigidity in response to a sustained load.

Rapid delivery of sediments from the Amazon River would have begun upon initial opening of the South Atlantic between 110 and $130 \mathrm{~m}$.y. ago. The load comprising the Amazon cone can, therefore, be assigned a characteristic time apprcaching $10^{8} \mathrm{yr}$, which would require a Maxwell decay constant of $10^{6}$ rather than $10^{5}$ yr (Waicott, 1970b, Fig. 5). Furthermore, the ages which Walcott assigned to two of his observations, the outer rises of island arc systems and the Hawaiian Archipelago, are too great. The age of the load in each case is about 2 m.y. rather than 10 m.y. This would require a deray constant closer to $10^{4}$ than $10^{5} \mathrm{yr}$. Walcott believes that this can be explained by a difference in the thickness of continental and ocearic lithosphere. If the lithosphere in oceanic regions was three-fourths of the continental thickness, then the relaxation curve for $10^{5}$-yr decay constant would pass through these points (Walcott, 1972, personal commun.).

There is still, however, the problem that the Amazon cone, with a rnuch greater time of loading, shows the same Aexural rigidity as the Hawaiian Archipelago and the outer rises. One explanation is that since a continental margin represents a transition zcne between continent and ocean, results obtained from a margin would be atypical. If, on the other hand, results obtained from the Amazon cone are characteristic of the response of the lithosphere to long-term loading, then it appears that the lithosphere shows some of the characteristics of a Kelvin (viscoelastic solid) material in that it approaches asymptotically some non-zero minimum apparent flexural rigidity. Since the flexural rigidity shown in response: to loads 
with ages of the order of $10^{6}$ and $10^{8} \mathrm{yr}$ are both near $2 \times 10^{30}$ dyne $\mathrm{cm}$, implying an apparent thickness of $30 \mathrm{~km}$, it seems that this is the minimum value and that it is reached within a few million years of loading.

\section{SUMMARY AND CONCLUSIONS}

1. The free-air gravity field in the Guiana Basin can be divided into short wave-length components directly correlatable to topographic and basement relief and longer wavelength regional components independent of bathymetry or basement topography. The regional field is quite negative throughout the basin.

2. Fracture zones maintain a characteristic gravity signature well away from the MidAtlantic Ridge crest. The gravity minimum becomes reduced as the trough is filled with sediments, leaving a gravity high over the fracture zone ridge to mark the presence of the fracture zone. Only about one-half the magnitude of the free-air gravity anomaly can be assigned to uncompensated topographic relief, implying that a mass excess is associated with fracture zones.

3. The magnetic anomalies over the large equatorial fracture zones show a characteristic peak over the fracture zone trough and offset from the topographic and gravity peaks. The consistency of the polarity of the spike from profile to profile over large distances implies that there is a zone of zero or reduced magnetization $20 \mathrm{~km}$ wide within a zone 50 to 60 $\mathrm{km}$ wide in which the magnetization is induced rather than remanent. The gravity and magnetic evidence together with published studies of the petrology of fracture zone rocks suggest that large fracture zones serve as the site of intrusion of large quantities of ultrabasic rocks from depth.

4. The gravity and topographic expressions of the North Brazilian Ridge do not coincide for much of the east-west segment of the ridge, which is associated with the St. Paul's fracture zone by Le Pichon and Hayes (1971). There is also a 15 - to 20 -mgal difference in the general values of the gravity anomalies on either side of this portion of the ridge, with the anomalies being lower on the landward side. A similar region of low gravity exists on the continental side of the eastern section of the North Brazilian Ridge, which is apparently continuous with the Romanche fracture zone (Fig. 1). Talwani and Eldholm (1973) have examined marginal escarpments of the coasts of
Norway and South Africa which they have interpreted as marking the boundary between oceanic and continental crust. Both of these escarpments were characterized by a negative isostatic gravity anomaly on their landward side. It is possible that sections of the North Brazilian Ridge represent a similar marginal escarpment. It is not possible, however, to state definitely that the ridge marks the boundary between continental and oceanic basement until the exact relation between the fracture zones and the North Brazilian Ridge can be worked out.

5. The deformation due to the sediment load of the Amazon cone indicates that the lithosphere near the continental margin behaves as an elastic beam with a flexural rigidity of $2 \times 10^{30}$ dyne $\mathrm{cm}$ and an effective thickness of $30 \mathrm{~km}$. The thickness of $30 \mathrm{~km}$ must be regarded an an "effective" thickness because the analysis considers the lithosphere to be homogeneous and because the lower boundary is undoubtedly gradational. Thirty $\mathrm{km}$ is considerably less than the value of $100 \mathrm{~km}$ determined for the thickness of the lithosphere through seismological means. It is, however, very similar to values obtained elsewhere from the response of the lithosphere to sustained loads. This suggests that the response of the lithosphere to long-term loading demonstrates some of the characteristics of a viscoelastic solid in that as time of loading increases, the apparent flexural rigidity approaches asymptotically some non-zero value. It should be noted, however, that the Amazon cone is situated at a continental margin which, as it is the location of the transition from ocean to continent, is a special case and may not be typical of the lithosphere in general.

\section{ACKNOWLEDGMENTS}

I am particularly indebted to $\mathrm{M}$. Talwani for his assistance in the conception and development of this research. B. J. Collette, D. E. Hayes, C. H. Scholz, and R. I. Walcott read the manuscript and offered valuable suggestions for its improvement. I would also like to acknowledge useful discussions with $\mathrm{R}$. W. Embley. This research was supported under Office of Naval Research Contract N0001467-A-0108-004 and National Science Foundation Grants GA-27281 and GX-34410. I have been partially supported by a National Science Foundation Graduate Fellowship. 


\section{REFERENCES CITED}

Aumento, F., and H. Loubat, 1971, The MidAtlantic Ridge near $45^{\circ}$ N.; XVI. Serpentinized ultramafic intrusions: Canadian Jour. Earth Sci., v. 8, p. 631-663.

Bonatti, E. 1968, Ultramafic rocks from the MidAtlantic Ridge: Nature, v. 219, p. 363-364.

Bonatti, E., Honnorez, J., and Ferrara, G., 1971, Peridotite-gabbro-basalt complex from the equatorial Mid-Atlantic Ridge: Royal Soc. London Philos. Trans., ser. A, v. 268, p. 385-402.

Bryan, G. M., Kumar, N., and deCastro, P. M., 1973, The North Brazilian Ridge and the extension of equatorial fracture zones into the continent: Brazilian Geol. Cong., 26th, Proc. (in press).

Cann, J. R., and Vine, F. J., 1966, An area on the crest of the Carlsberg Ridge: Petrology and magnetic survey: Royal Soc. London Philos. Trans., ser. A, v. 259, p. 198-219.

Creer, K. M., 1970, A review of paleomagnetism: Earth-Sci. Rev., v. 6, p. 369--466.

Edgar, N. T., and Ewing, J., 1968, Seismic refraction measurements on the continental margin of northeastern South America [abs.]: Am. Geophys. Union Trans., v. 49, p. 199.

Embley, R., Hayes, D. E., and Damuth, J. E., 1972, The Ceara Rise: Western equatorial Atlantic [abs.]: EOS (Am. Geophys. Union Trans.), v. 53, 4, p. 408.

Francheteau, J., and Le Pichon, X., 1972, Marginal fracture zones as structural framework of continental margins in the South Atlantic Ocean: Am. Assoc. Petroleum Geologists Bull., v. 56 , p. $891-907$.

Gunn, R., 1943, A quantative evaluation of the influence of the lithosphere on the anomalies of gravity: Franklin Inst. Jour., v. 236, p. 47-65.

- 1944 , A quantative study of the lithosphere and gravity anomalies along the Atlantic Coast: Franklin Inst. Jour., v. 237, p. 139-154.

Hatherton, T., 1967, A geophysical study of Nelson-Cook Strait region, New Zealand: New Zealand Jour. Geology and Geophysics, v. 10, p. 1330-1347.

Hayes, D. E., and Ewing, M., 1969, The structure of the north Brazilian continental margin: Geol. Soc. America, Abs. with Programs for 1969, Spec. Paper 121, p. 130-131.

_ 1970, North Brazilian Ridge and adjacent continental margin: Am. Assoc. Petroleum Geologists Bull., v. 54, p. 2120-2150.

Heezen, B. C., Bunce, E. 'T., Hersey, J. B., and Tharp, M., 1964a, Chain and Romanche fracture zones: Deep-Sea Research, v. 11, p. 11-33.

Heezen, B. C., Gerard, R. B., and Tharp, M., $1964 \mathrm{~b}$, The Vema Fracture Zone in the equatorial Atlantic: Jour. Geophys. Research, v. 69 , p. $733-739$.

Heezen, B. C., Fox, P. J., Johnson, G. L., Tharp, M., and Ballard, A., 1969, A fracture zone at $8^{\circ} \mathrm{N}$ : Am. Geophys. Union Trans., v. 50, 4, p. 211.

Hekinian, R., 1968, Rocks f:om the Mid-Ocean Ridge in the Indian Ocean: Deep-Sea Research, v. 15, p. 195-213.

Holoman, J. N., 1968, The sediment yield of major rivers of the world: Water Resources Research, v. 4, p. 787-79'7.

Kaula, W. M., 1972, Global gravity and tectonics, in Robertson, E. C., ed. The nature of the solid earth: New York, McGraw-Hill, p. 385-405.

Le Pichon, X., and Hayes, D. E., 1971, Marginal offsets, fracture zones and the early opening of the South Atlantic: Jour. Geophys. Research, v. 76, p. 6283-6293.

Matthews, D. H., Vine, F. S., and Cann, J. R., 1965, Geology of an area of the Carlsberg Ridge, Indian Ocean: 'Seol. Soc. America Bull., v. 76 , p. $675-682$.

Melson, W. G., and Thompson, G., 1971, Petrology of a transform faul: zone and adjacent ridge segments: Royal Soc. London Philos. Trans., ser. A, v. 268, p. 423-441.

Mesner, J. C., and Wooldridge, L.C.P., 1964, Maranhao Paleozoic basin and Cretaceous coastal basins, northern Brazil: Am. Assoc. Petroleum Geologists Bull., v. 48, p. 14751512.

Miyashiro, A., Shido, F., and Ewing, M., 1969, Composition and origin of serpentinites from the Mid-Atlantic Ridge near $24^{\circ}$ and $30^{\circ}$ North atitude: Contr. Minerology and Petrology, v. 23, p. 117-127.

Miyashiro, A., Shido, F., and Ewing, M., 1971, Metamorphism in the Mid-Atlantic Ridge near $24^{\circ}$ and $30^{\circ} \mathrm{N}$ : Royal Soc. London Philos. Trans., ser. A, v. 268, p. 589-603.

Nicholls, G. D., Nalwalk, A. J., and Hay:, E. E., 1964, The nature and composition of rock samples dredged from the Mid-Atlantic Ridge between $27^{\circ}$ and $52^{\circ} \mathrm{N}$ : Marine Geology, v. 1 p. 333-34.3.

Olivet, J. L., Le Pichon, X., Monti, S., Sichler, B., and Pautot, G., 1973, The Gibbs Fracture Zone between $35^{\circ}$ and $49^{\circ} \mathrm{W}$ : Jour. Geophys. Research (in press).

Opdyke, N. D., and Hekiniarı, R., 1967, Magnetic properties of some igntous rocks from the Mid-Atlantic Ridge: Jour. Geophys. Research, v. 72, p. 2257-2260.

Pitman, W. C., III, and Talwani, M., 1972, Seafloor spreading in the North Atlantic: Geol. Soc. America Bull., v. 83, p. 619-646.

Shand, S. J., 1949, Rocks of the Mid-Atlantic Ridge: Jour. Geology, v. 57, p. 89-92.

Talwani, M., and Eldholm, O., 1973, The boundary 
between continental and oceanic crust at the margin of rifted continents: Nature, v. 241, p. 325-330.

Talwani, M., Worzel, J. L., and Landisman, M., 1959, Rapid gravity computations for twodimensional bodies with application to the Mendocino submarine fracture zone: Jour. Geophys. Research, v. 64, p. 49-59.

Talwani, M., Poppe, H. R., and Rabinowitz, P. D., 1972, Gravimetrically determined geoid in the western North Atlantic, in Sea surface topography from space, Vol. 2: NOAA Tech. Rept. ERL-228-AOML 7-2, p. 1-34.

Thompson, G., and Melson, W. G., 1972, The petrology of oceanic crust across fracture zones in the Atlantic Ocean: Evidence of a new kind of sea-floor spreading: Jour. Geology, v. 80 , p. 526-538.

Timoshenko, S., 1956, Strength of materials (3d ed.): Princeton, N.J., D. Van Nostrand Co., $442 \mathrm{p}$.

van Andel, Tj. H., Corliss, J. B., and Bowen, V. T., 1967, The intersection between the MidAtlantic Ridge and the Vema Fracture Zone in the North Atlantic: Jour. Marine Research, v. 25 , p. $343-351$.
Vening Meinesz, F. A., 1948, Gravity expeditions at sea, 1923-1938 (4 vols.): Delft, Netherlands Geod. Comm.

Vogt P. R., Anderson, C. N., and Bracey, D. R., 1971, Mesozoic magnetic anomalies, sea floor spreading, and geomagnetic reversals in the southwestern North Atlantic: Jour. Geophys. Research, v. 76, p. 4796-4823.

Walcott, R. I., 1970a, Flexure of the lithosphere in Hawaii: Tectonophysics, v. 9, p. 435-446.

- 1970b, Flexural rigidity, thickness, and viscosity of the lithosphere: Jour. Geophys. Research, v. 75, p. 3941-3954.

- 1972, Gravity, flexure, and the growth of sedimentary basins at a continental edge: Geol. Soc. America Bull., v. 83, p. 1845-1848.

Worzel, J. I.., 1965, Pendulum gravity measurements at sea 1936-1959: New York, John Wiley \& Sons, Inc., 422 p.

Manuscript Received by the Society December 7, 1972

Revised Manuscript Received April 16, 1973

Lamont-Doherty Geological Observatory Contribution No. 1998 